EmTEd by ROBERT M. HENDERSHOT and STEVE MARSH

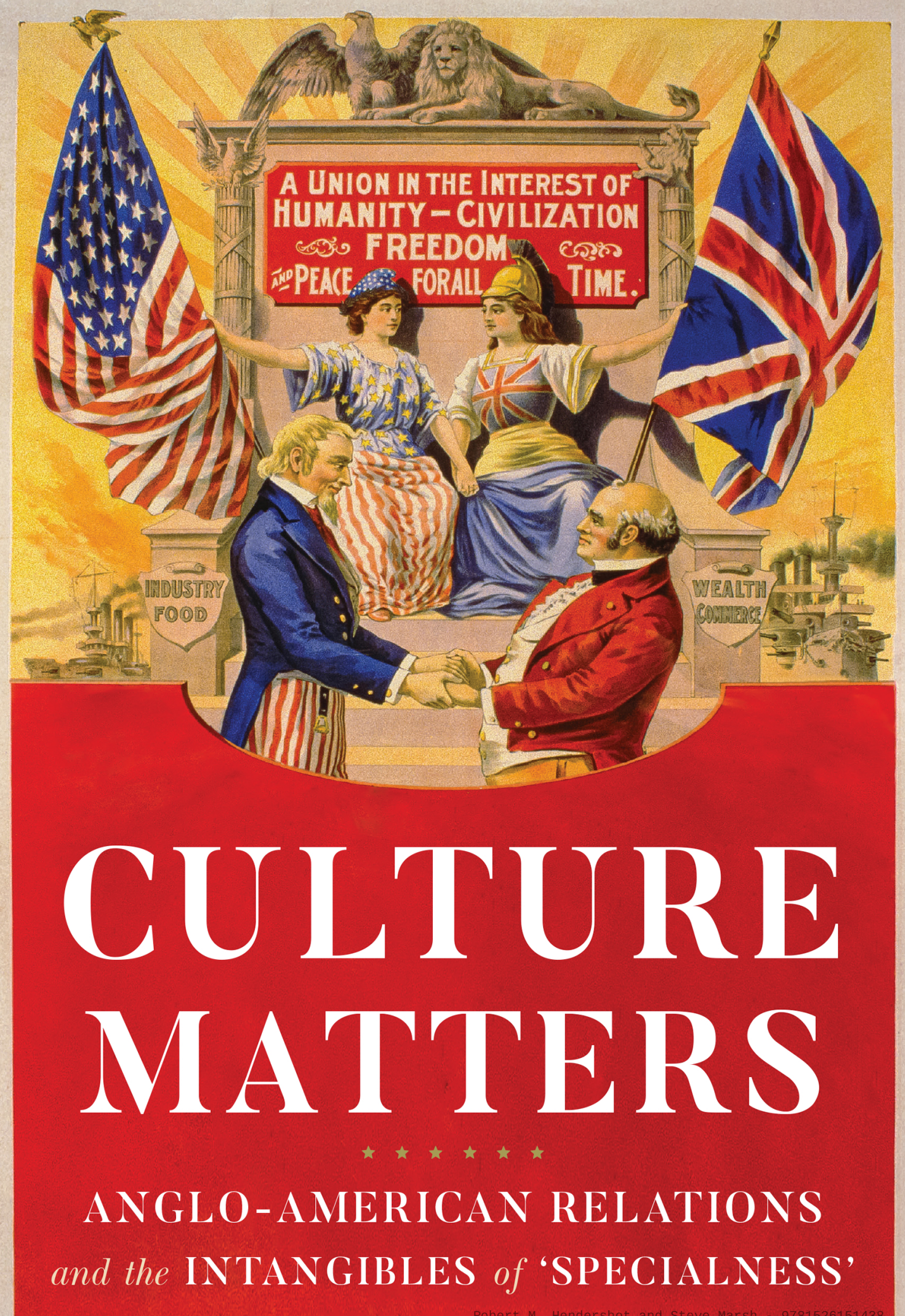




\section{Culture matters}

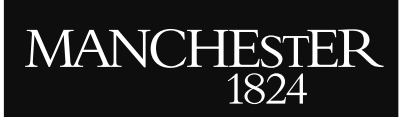

Manchester University Press 
Robert M. Hendershot and Steve Marsh - 9781526151438 Downloaded from manchesterhive.com at 04/26/2023 12:37:55AM 


\section{Culture matters}

Anglo-American relations and the intangibles of 'specialness'

\section{EDITED BY ROBERT M. HENDERSHOT AND STEVE MARSH}




\section{Copyright (c) Manchester University Press 2020}

While copyright in the volume as a whole is vested in Manchester University Press, copyright in individual chapters belongs to their respective authors, and no chapter may be reproduced wholly or in part without the express permission in writing of both author and publisher.

Published by Manchester University Press

Altrincham Street, Manchester M1 7JA www.manchesteruniversitypress.co.uk

British Library Cataloguing-in-Publication Data

A catalogue record for this book is available from the British Library

ISBN 9781526151421 hardback

First published 2020

The publisher has no responsibility for the persistence or accuracy of URLs for any external or third-party internet websites referred to in this book, and does not guarantee that any content on such websites is, or will remain, accurate or appropriate.

Cover image: 'A union in the interest of humanity - civilization - freedom - and peace for all time', c. 1898. @ Donaldson Litho Company / Library of Congress Prints and Photographs Division, Washington, D.C.

Typeset by Newgen Publishing UK 